Marquette University

e-Publications@Marquette

Chemistry Faculty Research and Publications

Chemistry, Department of

$1-1-2016$

\title{
A Flipped Classroom Redesign in General Chemistry
}

Scott Reid

Marquette University, scott.reid@marquette.edu

Accepted version. Chemistry Education Research and Practice, Vol. 17 (2016): 914-922. DOI. (C) 2016 The Royal Society of Chemistry. Used with permission. 


\title{
A Flipped Classroom Redesign in General Chemistry
}

\author{
Scott A. Reid \\ Department of Chemistry, Marquette University \\ Milwaukee, WI
}

\begin{abstract}
The flipped classroom continues to attract significant attention in higher education. Building upon our recent parallel controlled study of the flipped classroom in a second-term general chemistry course (J. Chem. Educ., 2016, 93, 13-23), here we report on a redesign of the flipped course aimed at scaling up total enrollment while keeping discussion sizes small (i.e., $<30$ students), and maintaining equivalent contact hour load for faculty and workload for students. To that end, the course format featured lecture contact pushed outside of the classroom in the form of video lectures (mean duration 13 minutes) paired with online homework sets, and three parallel weekly one-hour discussion sections were held in adjoining lab rooms immediately prior to the three-hour laboratory session. As in our previous design, the discussion sections were led by teaching assistants; however, the weekly discussion meeting was shortened from 75 minutes to 50 minutes, and the primary instructor "floated" between the three parallel sessions. Two such sessions were held each week, affording a possible enrollment of 144; initial enrollment was 141, with students self-selecting into the course. We examine student performance in and satisfaction with the course using: (1) a pre-test/post-test design based on the paired questions American Chemical Society (ACS) first-term and second-term exams, (2) data on DFW (D, F, withdrawal) rates, and (3) student evaluations.
\end{abstract}

\section{Introduction}

Over the past 15 years (Baker, 2000; Lage and Platt, 2000; Lage et al., 2000), the flipped classroom concept has continued to gain much attention, at all education levels, and in fields ranging from medicine and the natural sciences to the social sciences and

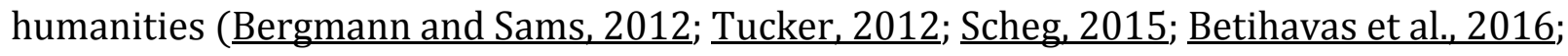

Chemistry Education Research and Practice, Vol. 17 (2016): pg. 914-922. DOI. This article is @ Royal Society of Chemistry and permission has been granted for this version to appear in e-Publications@Marquette. Royal Society of Chemistry does not grant permission for this article to be further copied/distributed or hosted elsewhere without the express permission from Royal Society of Chemistry. 
Boyle et al., 2016; Buxton et al., 2016; Eichler and Peeples, 2016; Foldnes, 2016; GonzalezGomez et al., 2016; Hanson, 2016; Hao, 2016a, 2016b; Hao and Lee, 2016; Hibbard et al. 2016; Hotle and Garrow, 2016; Huang and Hong, 2016; Janotha, 2016; Koo et al., 2016; Kvashnina and Martynko, 2016; Li et al., 2016; Liebert et al., 2016; Liou et al., 2016; McEvoy et al., 2016; McLean et al., 2016; Nash et al., 2016; Ojennus, 2016; Peterson, 2016; Pienta, 2016; Porcaro et al., 2016; Rotellar and Cain, 2016; Ryan and Reid, 2016; Schneider and Blikstein, 2016; Shaffer, 2016; Sockalingam et al., 2016; $\underline{\text { Sohrabi and Traj, 2016; }}$ Wieczkowski et al., 2016; Yu and Wang, 2016). Built upon the framework of active learning (Sirhan et al., 1999; Sirhan and Reid, 2001), different models of the flipped classroom exist (Lage and Platt, 2000; Lage et al.. 2000; Christiansen, 2014), yet each share a common emphasis on interactive problem solving and application, with lecture content usually pushed outside of the classroom, e.g., in the form of videos paired with online homework sets (Bergmann and Sams, 2014). Consistent with this notion, Abeysekera and Dawson have recently provided a concise definition of the flipped approach that involves three key pedagogical features (Abeysekera and Dawson, 2015): (1) rote information-conveying teaching is moved outside of class; (2) class time is reserved for active and social learning approaches; and (3) students are required to complete activities outside of class in order to maximize the benefits of the in-class time. At its core, the flipped classroom seeks to "flip" the role of the instructor in the classroom, from a focus on explaining and demonstrating concepts to guiding and enabling students in their learning.

Peer-reviewed studies of the flipped classroom in the natural and physical sciences are emerging (Baepler et al., 2014; Bidwell, 2014; Christiansen, 2014; Fautch, 2015; Flynn, 2015; Hibbard et al., 2016; Ryan and Reid, 2016; Schultz et al., 2014; Seery, 2015; Seery and Donnelly, 2012; Trogden, 2015; Weaver and Sturtevant, 2015), with data suggesting that the flipped classroom offers advantages for underprepared and at-risk students, and is effective in reducing DFW (D, F, withdrawal) rates (Hibbard et al., 2016; Ryan and Reid, 2016; Trogden, 2015). Studies in higher education have also reported a high level of student satisfaction with the flipped class (Smith, 2013; Yeung and O'Malley, 2014; Flynn, 2015; Ryan and Reid, 2016).

Given these potential benefits of the flipped classroom, methods for scale-up are highly desirable. Some flipped implementations have incorporated large class formats; illustrative of this is a recent report of a parallel study (without pretest) in a large enrollment class (Yestrebsky, 2015), where an increase in student grades in the flipped class was observed, but no reported difference on standardized final exam scores was found between the control and flipped sections. Weaver has recently suggested one model for extending the flipped approach to a large (e.g., 400 student) general chemistry lecture,

Chemistry Education Research and Practice, Vol. 17 (2016): pg. 914-922. DOI. This article is @ Royal Society of Chemistry and permission has been granted for this version to appear in e-Publications@Marquette. Royal Society of Chemistry does not grant permission for this article to be further copied/distributed or hosted elsewhere without the express permission from Royal Society of Chemistry. 
which involved large discussion sections (of order 100 students) meeting on a twice monthly pattern (Weaver and Sturtevant, 2015). Success in scale-up of interactive learning approaches in introductory courses has been demonstrated in specially designed spaces; e.g., the SCALE-UP project at North Carolina State (Beichner, 2007). While such spaces do not exist at present at our institution, we were nonetheless intrigued by the idea of expanding the flipped classroom experience to a larger fraction of the nearly 600 students who enroll in our second-term general chemistry course.

At the core of this interest lay the positive results reported from our recent parallel controlled study of the flipped classroom, which demonstrated reduced DFW rates and improved student outcomes for the bottom student demographic as measured either by pretest score or prior course rank (Ryan and Reid, 2016). That course featured four weekly 75 minute discussion sections, with a total enrollment of 117 . In the resigned format described here, we sought to scale up enrollment in the flipped classroom while keeping discussion size small (i.e., <30 students), to ensure significant instructor-student interaction, and maintaining instructor effort equivalent to that of the traditional lecturebased course. To that end, we adopted a design where, for each section, 3 parallel 50 minute discussions were held in adjoining laboratory rooms, capped at 24 students per room. To foster increased connections with the laboratory, and also increase efficiency in student scheduling, the discussions were scheduled immediately prior to the three-hour laboratory. This timeblock, then, represented our only face-to-face meeting with the students each week. A teaching assistant (TA) led each discussion, and the primary instructor "floated" between the rooms during the discussion period. Given the current pattern of laboratory scheduling at Marquette, it was possible to offer two sections of the flipped course, thereby affording a maximum enrollment of 144 (72 per section) in the initial implementation.

As in our prior study, enrollment in the spring flipped classroom was entirely selfselected. However, the same primary instructor had taught a lecture section of the firstterm course in fall, where the ACS first-term paired questions exam (form 2005) was given, and 69 students from that course enrolled in the spring flipped course, which had a total initial enrollment of 141 . Students in the spring course were administered the second-term general chemistry ACS paired questions exam (form 2007) (Holme and Murphy, 2011). Using the pretest/posttest data, data on DFW rates, and student evaluations of the course, we sought to answer the following questions:

(1) What effect, if any, does a parallel scale-up have on student performance in a second-term general chemistry flipped classroom?

Chemistry Education Research and Practice, Vol. 17 (2016): pg. 914-922. DOI. This article is @ Royal Society of Chemistry and permission has been granted for this version to appear in e-Publications@Marquette. Royal Society of Chemistry does not grant permission for this article to be further copied/distributed or hosted elsewhere without the express permission from Royal Society of Chemistry. 
(2) What effect, if any, does the course redesign have on DFW rates?

(3) What is the effect of the model on student opinions of the course and instructor?

\section{Theoretical framework}

The flipped classroom has been recently placed within the framework of educational theories, including cognitive load theory (CLT) and self-determination theory (SDT) (Seery and Donnelly, 2012; Abeysekera and Dawson, 2015). For the former, the selfpaced interaction of students with lecture material prior to a structured engagement (i.e., discussion or class) may lead to a reduction in working memory load as compared with a traditional didactic lecture (Clarke et al., 2005; van Merrienboer and Sweller, 2005; Abeysekera and Dawson, 2015). In this vein, we note that our implementation features all content of the traditional didactic lecture in the video lectures, including both content transmission and worked examples. As another advantage, the flipped classroom may enhance the ability to tailor content to specific student level (Abeysekera and Dawson, 2015). Connecting with SDT, it has been suggested that the flipped classroom may enhance both intrinsic and extrinsic student motivation (Abeysekera and Dawson, 2015; Weaver and Sturtevant, 2015).

\section{Methodology}

\section{Population studied}

This study was carried out in a second-term non-majors general chemistry course. A separate majors course was available, and two separate lecture-based sections of the nonmajors course were also offered. The traditional general chemistry course design at Marquette features lecture sections of typical enrollment 200-250 taught by a primary instructor, with separate laboratory and discussion sections taught by graduate teaching assistants. Considering the group of 69 (out of 213 total) students in the primary instructor's fall non-flipped course first-term course who continued into the second-term flipped section, demographic information is provided in Table 1, where mean student

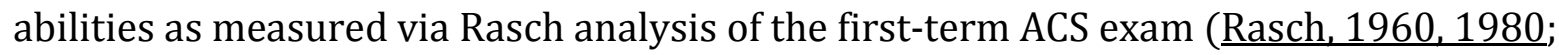

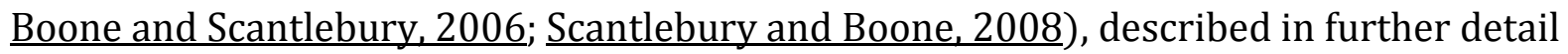
below, are given.

Chemistry Education Research and Practice, Vol. 17 (2016): pg. 914-922. DOI. This article is @ Royal Society of Chemistry and permission has been granted for this version to appear in e-Publications@Marquette. Royal Society of Chemistry does not grant permission for this article to be further copied/distributed or hosted elsewhere without the express permission from Royal Society of Chemistry. 
Table 1 Summary of demographic information for students in the instructor's fall first-term course, comparing all students with those who entered the flipped second-term section

\begin{tabular}{|c|c|c|c|c|}
\hline Item & Flipped 2nd term & & All students & \\
\hline$N_{\text {total }}$ & 69 & & 213 & \\
\hline Gender & $74 \% \mathrm{~F}, 26 \% \mathrm{M}$ & & $56 \% \mathrm{~F}, 44 \% \mathrm{M}$ & \\
\hline \multirow{7}{*}{ Major } & Engineering & $13.3 \%$ & Engineering & $34.7 \%$ \\
\hline & Health Sciences & $52.9 \%$ & Health Sciences & $33.3 \%$ \\
\hline & Biology & $17.6 \%$ & Biology & $16.9 \%$ \\
\hline & Arts \& Sciences ${ }^{a}$ & $5.9 \%$ & Arts \& Sciences ${ }^{a}$ & $8.9 \%$ \\
\hline & Biochemistry & $5.9 \%$ & Biochemistry & $3.8 \%$ \\
\hline & Chemistry & $2.9 \%$ & $\begin{array}{l}\text { Chemistry } \\
\text { Che }\end{array}$ & $0.9 \%$ \\
\hline & Other & $1.5 \%$ & Other & $1.4 \%$ \\
\hline ACS mean (SD) $^{b}$ & $28.1(6.1)$ & & & $25.3(8.8)$ \\
\hline Student ability (b) ${ }^{c}$ & $1.16(0.89)$ & & & $0.97(0.94)$ \\
\hline
\end{tabular}

${ }^{a}$ Arts and Sciences = other majors in A\&S than those listed or undeclared. ${ }^{b}$ Mean score (one standard deviation in parenthesis) on ACS first-term paired questions exam. ${ }^{c}$ Mean student ability as derived from Rasch text for details).

\section{Course format}

The redesigned course structure held to the fundamental design principle of equivalent expectations for student effort as compared with the lecture-based version. The redesign is illustrated schematically in Fig. 1. The course consisted of two sections, which met each week either on M (Section 1) or W (Section 2). At each meeting, three parallel 50 minute discussions were held in adjoining laboratory rooms featuring seating in the round in groups of 4 with 24 students per room, leading to a total possible enrollment of 144 students (72 per section). The initial course enrollment was 141 . A TA led each section, and the primary instructor, equipped with a large tablet computer, "floated" between the rooms during the discussion period. In practice, this allowed the instructor to effectively interact with small groups (4 students) of students. In order to foster increased connections with the laboratory, and also increase efficiency in student and TA scheduling, the discussion was scheduled immediately prior to the three-hour laboratory, so that the discussion TA also served as instructor for the laboratory component. 


\section{Flipped Redesign}

\begin{tabular}{|l|c|c|}
\hline Activity & Discussion & Laboratory \\
Timeline & $50 \mathrm{~min}$ & $2 \mathrm{~h} 50 \mathrm{~min}$ \\
\hline
\end{tabular}

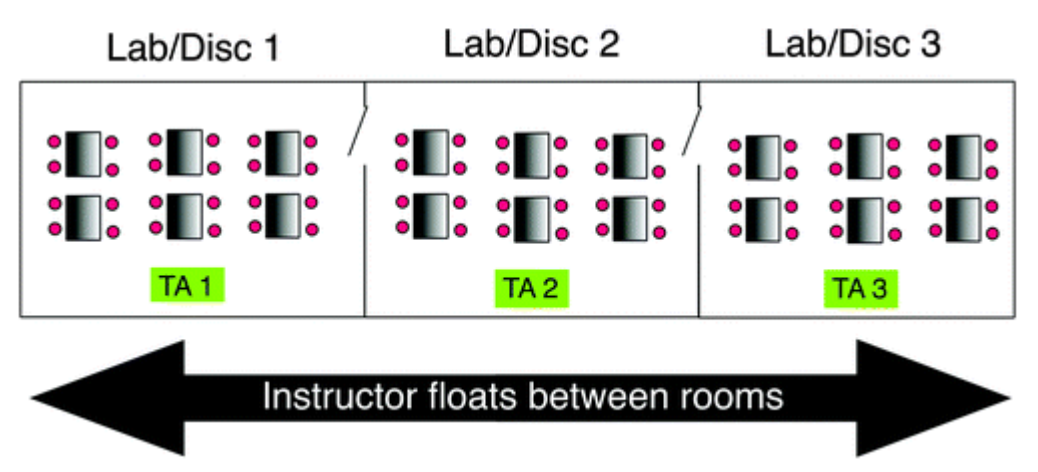

Fig. 1 Schematic of the flipped classroom design.

Three video lectures (Ryan and Reid, 2016) were typically assigned each week. These were made available only on the course management system, and each was paired with an assignment delivered using the SAPLING online-homework system ( $\underline{\text { Sapling, 2016). }}$. Two chances were given to complete each assignment; these were available for credit only within a one-week period. Following the completion of all homework sets for a given module, an additional extra credit set was opened for that module and kept open until the module exam. This set allowed students to gain back points on the homework, and unlimited attempts were allowed for these questions, with a small (5\%) deduction for incorrect attempts.

The discussion format was primarily problem solving; however, occasionally short "microlectures" (1-2 slide lectures) were included (Sweet, 2014). Participation points were awarded for: (1) discussion attendance, and (2) posting questions to the online discussion board on the course management system (one question or response to a question per module). The discussion sets were then written "just-in-time", after reviewing performance on the homework sets and discussion board queries.

\section{Student evaluations}

Student evaluation data were collected using the standard University Online Course Evaluation, a 15 item six level Likert scale questionnaire, which also contained a free

Chemistry Education Research and Practice, Vol. 17 (2016): pg. 914-922. DOI. This article is @ Royal Society of Chemistry and permission has been granted for this version to appear in e-Publications@Marquette. Royal Society of Chemistry does not grant permission for this article to be further copied/distributed or hosted elsewhere without the express permission from Royal Society of Chemistry. 
commentary section. The evaluation submission window was opened at the end of term, prior to final exams; results were made available after submission of final course grades.

\section{IRB approval}

Our flipped classroom study was reviewed and exemption granted by the Institutional Review Board.

\section{Results}

\section{Pretest/posttest exam performance}

We first compare pretest/posttest scores on the ACS paired-question exams for the 69 students common to both courses. The national normed data allows scaling of the exams, using the corresponding mean $(\mu)$ and standard deviation $(\sigma)$ for each exam, obtained from the ACS exams institute. The scaled scores were derived from the raw scores $\left(\mathrm{x}_{\mathrm{i}}\right)$ using the formula:

$$
S_{i}=\frac{x_{i}-\mu}{\sigma}
$$

The average scaled score (one standard deviation, SD, in parenthesis) on the second-term ACS exam was 0.91 (0.81). On the first-term exam, the average was 0.68 (0.82). Using a two-tailed t-test for paired samples, which is consistently employed throughout this article, these scores are statistically different at the $\mathrm{p}<0.005$ level, with a moderate effect size of 0.47 .

Beyond using national norms, Rasch analysis of these items was also performed, where the Rasch model for dichotomous data expresses the probability of a correct answer for a given item (i) by a given person ( $n$ ) in terms of item difficulty $\left(\delta_{\mathrm{i}}\right)$ and ability $\left(\beta_{\mathrm{n}}\right)$ parameters (Rasch, 1960, 1980; Boone and Scantlebury, 2006; Scantlebury and Boone, 2008):

$$
P\left(X_{n i}=1\right)=\frac{\mathrm{e}^{\left(\beta_{n}-\delta_{t}\right)}}{1+\mathrm{e}^{\left(\beta_{n}-\delta_{i}\right)}}
$$


These parameters can be expressed on a logit (=log(odds)) scale which displays both person and item parameters; such scales are commonly referred to as Wright maps (Wilson, 2003). Fig. 2 shows Wright maps generated from separate analysis of the firstterm and second-term ACS exams for the 69 common students. When the item parameters were estimated simultaneously in order to place the exams on the same scale, the resulting scores (SDs) were 1.07 (0.82) for the second-term exam and 1.03 (0.87) for the first-term exam; these were not statistically different $(\mathrm{p}<0.05)$.
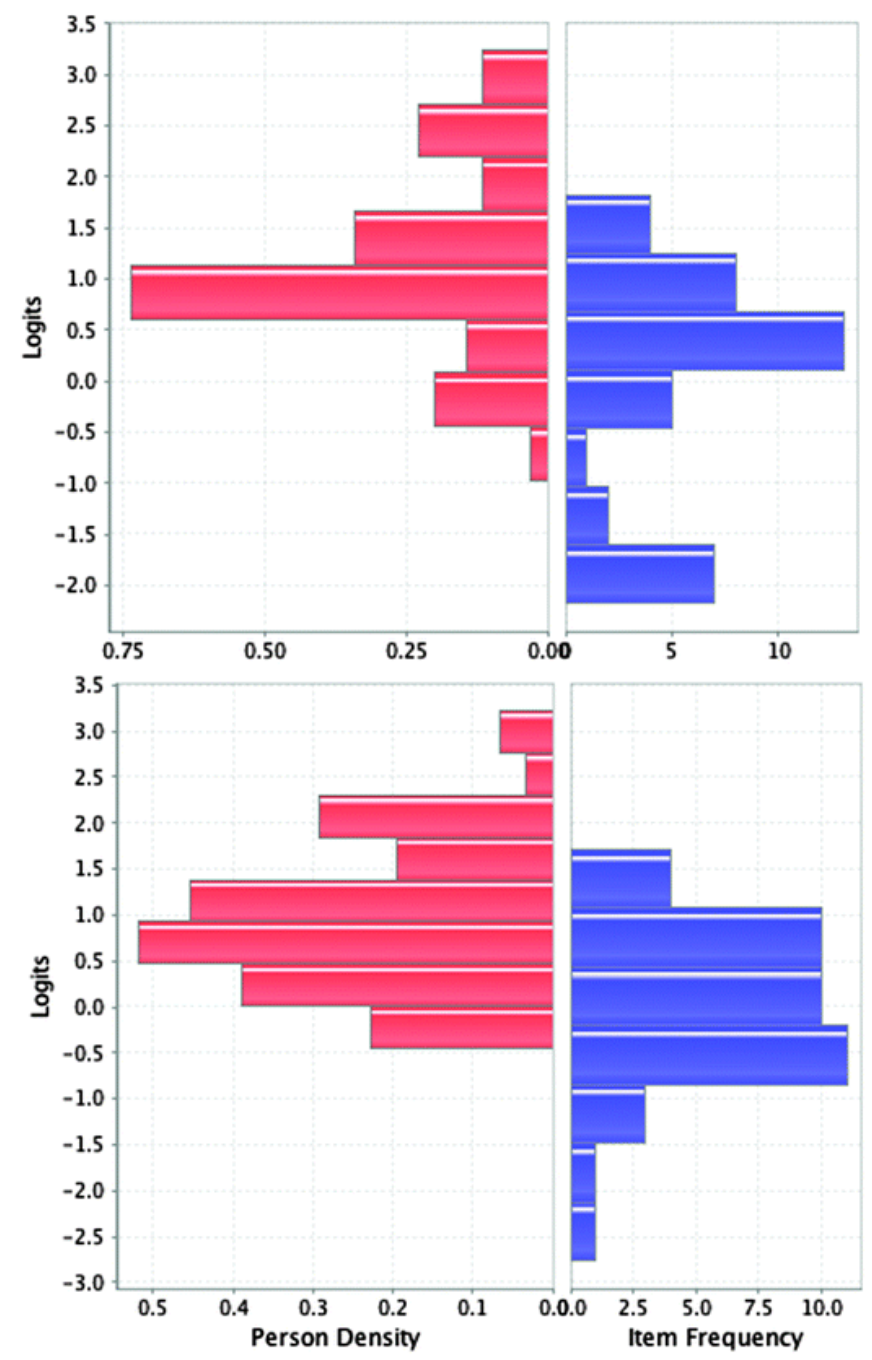

Fig. 2 Wright maps from Rasch analysis of the first-term ACS test (upper panel) and second-term ACS test for the 69 common subjects.

For the common student set, we also examined differential performance on the algorithmic and conceptual question pairs, using the pairing grids provided by the ACS exams institute. For the first term exam, the mean ability parameter (SD) for the 
conceptual questions was 1.34 (0.98), and for the algorithmic questions, 1.19 (1.12). These were not statistically different $(\mathrm{p}<0.05)$. For the second-term exam, the results were 0.86 (0.80) for conceptual questions and 1.20 (1.15) for algorithmic. These results were statistically different $(\mathrm{p}<0.005)$, with a modest effect size $(0.35)$. When the entire second term class was considered, this trend persisted; abilities were 0.77 (0.89) for conceptual questions, 1.12 (1.13) for algorithmic ( $p<0.001)$, with a similar effect size $(0.35)$.

\section{Failure and withdrawal rates}

Addressing our second research question, data concerning the DFW (D, F, withdrawal) rate (or DFW\%) was considered. In our prior study, the flipped classroom exhibited a reduction in DFW\% of some 56\%, in comparison with the control course and historical course data. This was remarkably consistent with a recent meta-analysis of active learning in STEM fields, which found a 55\% decrease in DFW rates when active learning was employed (Freeman et al., 2014). Particularly notable in our prior study was the reduction in withdrawals; $1.6 \%$ (flipped) vs. $6.3 \%$ (control). The present study is consistent with our previous findings; (Ryan and Reid, 2016) here, the percentage of withdrawals was $2.1 \%$, while the overall DFW rate was $3.5 \%$, comparable to the rate of $3.4 \%$ previously reported.

\section{Correlations of overall exam performance with homework score}

Earlier (Ryan and Reid, 2016), we had observed that the association of overall exam performance with online homework score was noticeably stronger in the flipped section (Pearson $r=0.44$ ) ( $\underline{\text { Cohen, 1988) }}$ ) as compared with the control ( $r=0.27)$. It was therefore of interest to compare these results for the redesigned course. In this case, as we had two types of sets, homework and extra credit, we broke the results down further, as given in Table 2. Considering the homework score (best attempt), an increased correlation ( $\mathrm{r}=$ $0.51)$ is observed, which is further strengthened $(r=0.57)$ if both homework and extra credit scores are included.

Table 2 Correlations of overall exam performance with homework score

$\begin{array}{llll}\text { Indicator } & \text { Comparison set } & \begin{array}{l}\text { Flipped spring 2016 } \\ \text { (Pearson r) }\end{array} & \begin{array}{l}\text { Flipped spring 2015 } \\ \text { (Pearson r) }\end{array} \\ \begin{array}{l}\text { Online homework } \\ \text { score }\end{array} & \begin{array}{l}\text { Homework score, best } \\ \text { attempt }\end{array} & 0.51 & 0.44 \\ & \begin{array}{l}\text { Homework score, plus extra } \\ \text { credit }\end{array} & -\end{array}$

Chemistry Education Research and Practice, Vol. 17 (2016): pg. 914-922. DOI. This article is @ Royal Society of Chemistry and permission has been granted for this version to appear in e-Publications@Marquette. Royal Society of Chemistry does not grant permission for this article to be further copied/distributed or hosted elsewhere without the express permission from Royal Society of Chemistry. 
NOT THE PUBLISHED VERSION; this is the author's final, peer-reviewed manuscript. The published version may be accessed by following the link in the citation at the bottom of the page.

$\begin{array}{llll}\text { Indicator } & \text { Comparison set } & \begin{array}{l}\text { Flipped spring 2016 } \\ \text { (Pearson } r \text { ) }\end{array} & \begin{array}{l}\text { Flipped spring 2015 } \\ \text { (Pearson r) }\end{array} \\ & \text { Extra credit only } & 0.47 & -\end{array}$

\section{Student evaluations and comments}

Addressing our third research question, data from student evaluations are compared in Table 3 with results from the Spring 2015 course; again, we emphasize that both courses featured student self-selection. No statistical difference $(p<0.05$, two-tailed t-test for independent samples) was found in evaluation items between the two sections. Mirroring the quantitative responses, student comments on the course were overall quite positive. Common positives noted for students who reported liking the flipped format were the lack of formal lectures, flexibility of the course, on-demand access of the lectures, and self-pacing with the ability to stop and rewind the lectures. These are consistent with

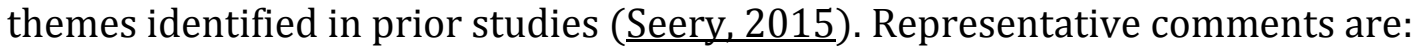

Table 3 Summary of student evaluations. Mean scores are shown, with one standard deviation given in parenthesis

Question

Key $\quad$ Flipped spring $2016 \quad$ Flipped spring 2015

Key 1: $6=$ excellent, $5=$ very good, $4=$ good, $3=$ fair, $2=$ poor, $1=$ very poor.Key $2: 6=$ strongly agree, 5 = agree, $4=$ agree somewhat, $3=$ neither agree nor disagree, $2=$ disagree somewhat, $1=$ strongly disagree.

\begin{tabular}{|c|c|c|c|}
\hline How was this class as a whole? & 1 & $4.69(0.75)$ & $4.90(0.89)$ \\
\hline How was the content of this class? & 1 & $4.73(0.77)$ & $4.73(0.80)$ \\
\hline The lab section as a whole was... & 1 & $4.32(0.66)$ & $4.50(0.71)$ \\
\hline $\begin{array}{l}\text { Coordination between lecture and lab } \\
\text { activities was... }\end{array}$ & 1 & $4.50(0.66)$ & $4.48(0.66)$ \\
\hline $\begin{array}{l}\text { This class positively impacted my } \\
\text { problem solving abilities. }\end{array}$ & 2 & $5.06(1.03)$ & $5.25(1.15)$ \\
\hline $\begin{array}{l}\text { This class was intellectually } \\
\text { challenging. }\end{array}$ & 2 & $5.60(1.57)$ & $5.46(1.42)$ \\
\hline $\begin{array}{l}\text { Evaluations were consistent with } \\
\text { course objectives. }\end{array}$ & 2 & $5.10(1.04)$ & $5.05(1.02)$ \\
\hline $\begin{array}{l}\text { Assistance or extra help were } \\
\text { available. }\end{array}$ & 2 & $5.52(1.5)$ & $5.50(1.45)$ \\
\hline $\begin{array}{l}\text { Expectations of students were } \\
\text { presented clearly. }\end{array}$ & 2 & $5.10(1.12)$ & $5.30(1.21)$ \\
\hline $\begin{array}{l}\text { The instructor provided explanations } \\
\text { that reduced confusion. }\end{array}$ & 2 & $5.27(1.27)$ & $5.58(1.51)$ \\
\hline The instructor was well organized. & 2 & $5.58(1.58)$ & $5.64(1.62)$ \\
\hline
\end{tabular}

Chemistry Education Research and Practice, Vol. 17 (2016): pg. 914-922. DOI. This article is @ Royal Society of Chemistry and permission has been granted for this version to appear in e-Publications@Marquette. Royal Society of Chemistry does not grant permission for this article to be further copied/distributed or hosted elsewhere without the express permission from Royal Society of Chemistry. 
NOT THE PUBLISHED VERSION; this is the author's final, peer-reviewed manuscript. The published version may be accessed by following the link in the citation at the bottom of the page.

$\begin{array}{llll}\text { Question } & \text { Key } & \text { Flipped spring 2016 } & \text { Flipped spring } 2015 \\ \begin{array}{l}\text { The instructor encouraged student } \\ \text { participation. }\end{array} & 2 & 5.13(1.10) & 5.48(1.38) \\ \begin{array}{l}\text { Number of responses } \\ \text { Response rate (\%) }\end{array} & - & 82 & 61 \\ & - & 59 \% & 54 \%\end{array}$

"I enjoyed the flipped classroom. Allowed for extra free time in my schedule."

"I absolutely loved the flipped classroom style of this class. This style of teaching worked especially well for me because I was able to pause and rewind lectures, watch lectures at any time of day, and re-watch lectures before exams."

"I liked not having to go to lecture because I already have a fundamental understanding of the chemistry we are learning, so the lectures did not seem necessary."

Common negatives reported by students who disliked the format were increased student responsibility for time management, and the fast pace of the videos; again, these echo student opinions expressed in earlier studies (Seery, 2015). Representative comments here included:

"The flipped schedule was just not for me, however it would have been better if I had utilized office hours and extra help."

"This was my first time doing a flipped classroom as a class and I'm not a big fan. It was difficult to keep track of what all needed to be done when. I also felt that we missed a lot of quality time for discussing content and example problems. I will not be taking another flipped classroom class."

"The flip class was not very ideal. The videos were too fast."

\section{Discussion}

Our previous controlled, parallel study of the flipped classroom found no overall difference $(p<0.05)$ in student performance (Ryan and Reid, 2016). However, improvement was evidenced in the bottom demographic, as measured either by pretest score or prior course ranking, and this trend was mirrored in a reduced DFW rate and, particularly, withdrawal percentage. In this work, we focus on a comparison of the redesigned course with our prior implementation.

Chemistry Education Research and Practice, Vol. 17 (2016): pg. 914-922. DOI. This article is @ Royal Society of Chemistry and permission has been granted for this version to appear in e-Publications@Marquette. Royal Society of Chemistry does not grant permission for this article to be further copied/distributed or hosted elsewhere without the express permission from Royal Society of Chemistry. 
Beginning with the pretest/posttest analysis, analysis of standardized ACS exam scores, when placed on the same scale, show no statistically meaningful difference $(\mathrm{p}<$ 0.05) for students in the flipped class as compared to the lecture-based first-term course. Thus, the present redesigned course did not negatively impact student performance, in comparison with our prior implementation. One meaningful distinction observed here between the flipped course and lecture-based first-term course was the finding of a statistically significant $(\mathrm{p}<0.005)$ difference in performance between conceptual and algorithmic questions on the second-term paired questions ACS final, with scores higher for the latter. This trend is opposite that observed in the study of Weaver (Weaver and Sturtevant, 2015), conducted in a majors class, where gains were greater for conceptual questions in the flipped class.

Considering the correlation of exam performance with homework, we had previously found a stronger correlation in the flipped class (yan and Reid, 2016), which was attributed in part to the fact that weekly assessments were broken down into smaller sets, paired with the content in each video, which had potential to reduce rates of unauthorized collaboration (i.e., cheating) (Stephens et al., 2007; Palazzo et al., 2010; Hamlen, 2012). The present study, which used a different online homework system, nonetheless demonstrated an equally high correlation of exam and homework performance, which was improved if both the regular homework and extra credit questions were included. As the latter featured unlimited attempts, with a small deduction for each incorrect attempt, and typically contained larger question pools, this format may also discourage unauthorized collaboration.

Turning to DFW rates, our previous study had exhibited a reduction in this rate that was very consistent with that found in a meta-analysis of active learning in chemistry and other STEM fields (Freeman et al., 2014). In this implementation, both the percentage of withdrawals and overall DFW rate were very similar to the Spring 2015 implementation (yan and Reid, 2016).

We next consider student engagement with the course. Participation points were awarded for attendance and posting questions/replies (1 per week) to the online discussion board. Some improvement in discussion attendance was expected by virtue of scheduling the discussion period immediately prior to the lab, and indeed the discussion attendance was increased overall (92\% for Spring 2016 course vs. 83\% for Spring 2015 course). Engagement with the online discussion board was also slightly increased; an average of 6.1 posts per student over the semester compared with 5.2 in our prior study. Nonetheless, the posting rate was roughly half that requested, and $20 \%$ of the class never

Chemistry Education Research and Practice, Vol. 17 (2016): pg. 914-922. DOI. This article is @ Royal Society of Chemistry and permission has been granted for this version to appear in e-Publications@Marquette. Royal Society of Chemistry does not grant permission for this article to be further copied/distributed or hosted elsewhere without the express permission from Royal Society of Chemistry. 
posted at all to the board. In our experience, some students are apprehensive about posting questions to a board when anonymity is disabled; however, anonymity is considered to defeat the overall aim of fostering online learning communities (Dede, 2004).

Student evaluations of the Spring 2016 course were very positive overall and consistent with those from Spring 2015. While not statistically significant, the impact of the parallel discussion format may be reflected in questions concerning the fostering of student participation and instructor explanations, which scored slightly lower. Concerning the correlation with the laboratory, the overall rating of the lab section was slightly lower than in our prior implementation, yet the rating of coordination between lecture and laboratory activities was similar. The flexibility and on-demand access of the flipped classroom continue to be noted as strengths; however, clearly, some students also struggle with the format of the course. In that vein, one request was for an additional instructor led discussion meeting on Friday.

\section{Conclusions}

We have reported on the redesign and implementation of a flipped classroom in a second-term general chemistry course, with the goal of scaling up course size while maintaining small discussion sizes (i.e., <30) and equivalent instructor and student effort to that of a lecture-based course. As is our previous study of the flipped classroom, the course model was publicized prior to registration and self-selection was allowed. Consistent with our prior findings, there was no overall statistical difference in ACS exam performance for students common to the flipped course and the first-term lecture-based course taught by the same instructor. However, a statistically significant difference in performance on algorithmic vs. conceptual questions (with algorithmic higher) was observed in the second term course. Correlation of exam performance with homework, overall DFW\%, and student evaluations were very comparable to that found in our prior study.

\section{Limitations}

As in our prior study, a limitation is the lack of authentic randomness in the student populations, which cannot be in practice achieved in a system of open registration. Again, we sought to overcome this through the use of a pretest. The demographic and academic profile of students who entered the flipped course from the instructor's fall-term course was considerably different from the fall course overall; however, part of this difference

Chemistry Education Research and Practice, Vol. 17 (2016): pg. 914-922. DOI. This article is @ Royal Society of Chemistry and permission has been granted for this version to appear in e-Publications@Marquette. Royal Society of Chemistry does not grant permission for this article to be further copied/distributed or hosted elsewhere without the express permission from Royal Society of Chemistry. 
reflected the change in sequencing of discussion and lab, which produced a conflict with the schedules of many engineering students.

\section{Implications}

Our results show that the flipped concept can be scaled up to reasonable size (144 students in two sections) while keeping discussion size small (24 students; 3 discussions run in parallel), and yet achieve many of the successes reported in our prior study, such as reduced DFW rates and high student satisfaction. Historically, general chemistry courses feature high first year DFW rates, and thus flipped courses continue to be one viable strategy for increased student success. The present redesign also suggests the potential for a 4 hour flipped blended lab/discussion as a potential meeting pattern, following upon studio designs for general chemistry courses (Apple and Cutler, 1999; Gottfried et al., 2007).

\section{Acknowledgements}

We thank Drs Michael Ryan, Rajendra Rathore, Llanie Nobile, and Adam Fiedler for helpful discussions on the flipped classroom.

\section{References}

Abeysekera L. and Dawson P., (2015), Motivation and cognitive load in the flipped classroom: definition, rationale and a call for research, Higher Educ. Res. Dev., 34(1), 1-14. DOI: http://10.1080/07294360.2014.934336.

Apple T. and Cutler A., (1999), The rensselaer studio general chemistry course, J. Chem. Educ., 76(4), 462-463.

Baepler P., Walker J. D. and Driessen M., (2014), It's not about seat time: Blending, flipping, and efficiency in active learning classrooms, Comput. Educ., 78, 227-236. DOI: http://10.1016/j.compedu.2014.06.006.

Baker J. W., (2000), The "Classroom Flip": Using Web Course Management Tools to Become the Guide by the Side. Paper presented at the Selected Conference Papers, Proceedings of the 11th International Conference on College Teaching and Learning, Jacksonville, FL.

Beichner R., (2007), The Student-Centered Activities for Large Enrollment Undergraduate Programs (SCALE-UP) Project Research-Based Reform of University Physics (Vol. 1).

Bergmann J. and Sams A., (2012), Flip Your Classroom: Reach Every Student in Every Class Every Day, Eugene, OR: International Society for Technology in Education.

Bergmann J. and Sams A., (2014), Flipped Learning: Gateway to Student Engagement, Eugene, OR: International Society for Technology in Education.

Chemistry Education Research and Practice, Vol. 17 (2016): pg. 914-922. DOI. This article is @ Royal Society of Chemistry and permission has been granted for this version to appear in e-Publications@Marquette. Royal Society of Chemistry does not grant permission for this article to be further copied/distributed or hosted elsewhere without the express permission from Royal Society of Chemistry. 
NOT THE PUBLISHED VERSION; this is the author's final, peer-reviewed manuscript. The published version may be accessed by following the link in the citation at the bottom of the page.

Betihavas V., Bridgman H., Kornhaber R. and Cross M., (2016), The evidence for 'flipping out': a systematic review of the flipped classroom in nursing education, Nurse Educ. Today, 38, 15-21. DOI: http://10.1016/j.nedt.2015.12.010.

Bidwell A., (2014), Flipped Classroom May Help Weaker STEM Students, U.S. News and World Report. http://www.usnews.com/news/stem-solutions/articles/2014/08/05/taking-a-page-fromhumanities-college-engineering-gets-flipped.

Boone W. J. and Scantlebury K., (2006), The role of Rasch analysis when conducting science education research utilizing multiple-choice tests, Sci. Educ., 90(2), 253-269. DOI: http://10.1002/sce.20106.

Boyle J. G., McEwen A. M., Carty D. M., McKay G. A., Gardiner K., Linn A. and Walters M. R., (2016), A flipped classroom approach to a 'Diabetes Acute Care Day' improves final year medical students' confidence and competence, Diabetic Med., 33, 133-133.

Buxton T., Buxton J. and Jackson A., (2016), Hybrid and Flipped Strategies in a Blended RN-BSN Program Determining Student and Faculty Perceptions, Nurse Educ., 41(1), 1-2. DOI: http://10.1097/NNE.0000000000000183.

Christiansen M. A., (2014), Inverted Teaching: Applying a New Pedagogy to a University Organic Chemistry Class, J. Chem. Educ., 91, 1845-1850.

Clarke T., Ayres P. and Sweller J., (2005), The impact of sequencing and prior knowledge on learning mathematics through spreadsheet applications, Educ. Technol. Res. Dev., 53(3), 15-24. DOI: http://10.1007/Bf02504794.

Cohen J., (1988), Statistical power analysis for the behavioral sciences, 2nd edn, Hillsdale, NJ: Erlbaum Associates.

Dede C., (2004), Enabling Distributed-Learning Communities via Emerging Technologies. Paper presented at the Proceedings of the 2004 Conference of the Society for Information Technology in Teacher Education (SITE), Charlottesville, VA.

Eichler J. F. and Peeples J., (2016), Flipped classroom modules for large enrollment general chemistry courses: a low barrier approach to increase active learning and improve student grades, Chem. Educ. Res. Pract., 17(1), 197-208. DOI: 10.1039/c5rp00159e.

Fautch J. M., (2015), The flipped classroom for teaching organic chemistry in small classes: is it effective? Chem. Educ. Res. Pract., 16(1), 179-186. DOI: 10.1039/c4rp00230j.

Flynn A. B., (2015), Structure and evaluation of flipped chemistry courses: organic \& spectroscopy, large and small, first to third year, English and French, Chem. Educ. Res. Pract., 16(2), 198-211. DOI: $10.1039 / \mathrm{c} 4 \mathrm{rp} 00224 \mathrm{e}$.

Foldnes N., (2016), The flipped classroom and cooperative learning: evidence from a randomised experiment, Act. Learn. Higher Educ., 17(1), 39-49. DOI: http://10.1177/1469787415616726.

Freeman S., Eddy S. L., McDonough M., Smith M. K., Okoroafor N., Jordt H. and Wenderoth M. P., (2014), Active learning increases student performance in science, engineering, and mathematics, Proc. Natl. Acad. Sci. U. S. A., 111, 8410-8415.

Gonzalez-Gomez D., Jeong J. S., Rodriguez D. A. and Canada-Canada F., (2016), Performance and Perception in the Flipped Learning Model: An Initial Approach to Evaluate the Effectiveness of a New Teaching Methodology in a General Science Classroom, J. Sci. Educ. Technol., 25(3), 450459. DOI: http://10.1007/s10956-016-9605-9.

Chemistry Education Research and Practice, Vol. 17 (2016): pg. 914-922. DOI. This article is @ Royal Society of Chemistry and permission has been granted for this version to appear in e-Publications@Marquette. Royal Society of Chemistry does not grant permission for this article to be further copied/distributed or hosted elsewhere without the express permission from Royal Society of Chemistry. 
NOT THE PUBLISHED VERSION; this is the author's final, peer-reviewed manuscript. The published version may be accessed by following the link in the citation at the bottom of the page.

Gottfried A. C., Sweeder R. D., Bartolin J. M., Hessler J. A., Reynolds B. P., Stewart I. C. and Holl M. M. B., (2007), Design and implementation of a studio-based general chemistry course, J. Chem. Educ., 84(2), 265-270, DOI:10.1021/ed084p265.

Hamlen K. R., (2012), Academic dishonesty and video game play: is new media use changing conceptions of cheating? Comput. Educ., 59(4), 1145-1152. DOI: http://10.1016/j.compedu.2012.06.001.

Hanson J., (2016), Surveying the experiences and perceptions of undergraduate nursing students of a flipped classroom approach to increase understanding of drug science and its application to clinical practice, Nurse Educ. Pract., 16(1), 79-85. DOI: http://10.1016/j.nepr.2015.09.001.

Hao Y. W., (2016a), Exploring undergraduates' perspectives and flipped learning readiness in their flipped classrooms, Comput. Hum. Behav., 59, 82-92. DOI: http://10.1016/j.chb.2016.01.032.

Hao Y. W., (2016b), Middle school students' flipped learning readiness in foreign language classrooms: exploring its relationship with personal characteristics and individual circumstances, Comput. Hum. Behav., 59, 295-303. DOI: http://10.1016/j.chb.2016.01.031.

Hao Y. W. and Lee K. S., (2016), Teaching in flipped classrooms: Exploring pre-service teachers' concerns, Comput. Hum. Behav., 57, 250-260. DOI: http://10.1016/j.chb.2015.12.022.

Hibbard L., Sung S. N. and Wells B., (2016), Examining the Effectiveness of a Semi -Self-Paced Flipped Learning Format in a College General Chemistry Sequence, J. Chem. Educ., 93(1), 24-30. DOI: http://10.1021/acsjcherned.5b00592.

Holme T. and Murphy K., (2011), Assessing Conceptual and Algorithmic Knowledge in General Chemistry with ACS Exams, J. Chem. Educ., 88(9), 1217-1222. DOI: http://10.1021/ed100106k.

Hotle S. L. and Garrow L. A., (2016), Effects of the Traditional and Flipped Classrooms on Undergraduate Student Opinions and Success, J. Prof. Issues Eng. Educ. Pract., 142(1), 05015005. DOI: http://10.1061/(Asce)Ei.1943-5541.<?ccdc_no 0000259?>0000259<?ccdc END?>.

Huang Y. N. and Hong Z. R., (2016), The effects of a flipped English classroom intervention on students' information and communication technology and English reading comprehension, Educ. Technol. Res. Dev., 64(2), 175-193. DOI: http://10.1007/s11423-015-9412-7.

Janotha B., (2016), Improving Student Achievement with Flipped Classroom Pedagogy, Nursing Res., 65(2), E100-E101.

Koo C. L., Demps E. L., Farris C., Bowman J. D., Panahi L. and Boyle P., (2016), Impact of Flipped Classroom Design on Student Performance and Perceptions in a Pharmacotherapy Course, Am. J. Pharm. Educ., 80(2), 33.

Kvashnina O. S. and Martynko E. A., (2016), Analyzing the Potential of Flipped Classroom in ESL Teaching, Int. J. Emerging Technol. Learn., 11(3), 71-73. D0I: http://10.3991/ijet.v11i03.5309.

Lage M. J. and Platt G., (2000), The Internet and the Inverted Classroom, J. Econ. Educ., 31, 11.

Lage M. J., Platt G. J. and Treglia M., (2000), Inverting the Classroom: A Gateway to Creating an Inclusive Learning Environment, J. Econ. Educ., 31, 30-43.

Li D. H., Jiang B. S., Li H. Y. and Liu X. P., (2016), Design of Experiment Course Computer-Aided Landscape Design Based on Flipped Classroom, Comput. Appl. Eng. Educ., 24(2), 234-240. DOI: http://10.1002/cae.21701.

Liebert C. A., Lin D. T., Mazer L. M., Bereknyei S. and Lau J. N., (2016), Effectiveness of the Surgery Core Clerkship Flipped Classroom: a prospective cohort trial, Am. J. Surg., 211(2), 451-U214. DOI: http://10.1016/j.amjsurg.2015.10.004.

Chemistry Education Research and Practice, Vol. 17 (2016): pg. 914-922. DOI. This article is @ Royal Society of Chemistry and permission has been granted for this version to appear in e-Publications@Marquette. Royal Society of Chemistry does not grant permission for this article to be further copied/distributed or hosted elsewhere without the express permission from Royal Society of Chemistry. 
NOT THE PUBLISHED VERSION; this is the author's final, peer-reviewed manuscript. The published version may be accessed by following the link in the citation at the bottom of the page.

Liou W. K., Bhagat K. K. and Chang C. Y., (2016), Beyond the Flipped Classroom: A Highly Interactive Cloud-Classroom (HIC) Embedded into Basic Materials Science Courses, J. Sci. Educ. Technol., 25(3), 460-473. DOI: http://10.1007/s10956-016-9606-8.

McEvoy C. S., Cantore K. M., Denlinger L. N., Schleich M. A., Stevens N. M., Swavely S. C., Odom A. A. and Novick M. B., (2016), Use of medical students in a flipped classroom programme in nutrition education for fourth-grade school students, Health Educ. J., 75(1), 38-46. DOI: http://10.1177/0017896914561879.

McLean S., Attardi S. M., Faden L. and Goldszmidt M., (2016), Flipped classrooms and student learning: not just surface gains, Adv. Phys. Educ., 40(1), 47-55. DOI: http://10.1152/advan.00098.2015.

Nash L., Austin C., Kornhaber R., Kumar S., Stone T., Saglam B., Brown D., Harris A., Boyce P., He R. and McLean L., (2016), To Flip or Not to Flip: An Evaluation of the Flipped Classroom Approach for Psychiatry Trainees, Aust. N. Z. J. Psychiatry, 50, 106-106.

Ojennus D. D., (2016), Assessment of Learning Gains in a Flipped Biochemistry Classroom, Biochem. Mol. Biol. Educ., 44(1), 20-27. DOI: http://10.1002/bmb.20926.

Palazzo D. J., Lee Y. J., Warnakulasooriya R. and Pritchard D. E., (2010), Patterns, correlates, and reduction of homework copying, Phys. Rev. ST - Phys. Educ. Res., 6(2), 029901. DOI: http://10.1103/Physrevstper.6.029901.

Peterson D. J., (2016), The Flipped Classroom Improves Student Achievement and Course Satisfaction in a Statistics Course: A Quasi-Experimental Study, Teach. Psychol., 43(1), 10-15. DOI: http://10.1177/0098628315620063.

Pienta N. J., (2016), A Flipped Classroom Reality Check, J. Chem. Educ., 93(1), 1-2. DOI: http://10.1021/acs.jchemed.5b00996.

Porcaro P. A., Jackson D. E., McLaughlin P. M. and O'Malley C. J., (2016), Curriculum Design of a Flipped Classroom to Enhance Haematology Learning, J. Sci. Educ. Technol., 25(3), 345-357. DOI: http://10.1007/s10956-015-9599-8.

Rasch G., (1960), Probabilistic Models for Some Intelligence and Attainment Tests, Copenhagen: Danish Institute for Educational Research.

Rasch G., (1980), Probabilistic Models for Some Intelligence and Attainment Tests (Expanded Edition), Chicago: The University of Chicago Press.

Rotellar C. and Cain J., (2016), Research, Perspectives, and Recommendations on Implementing the Flipped Classroom, Am. J. Pharm. Educ., 80(2), 34.

Ryan M. D. and Reid S. A., (2016), Impact of the Flipped Classroom on Student Performance and Retention: A Parallel Controlled Study in General Chemistry, J. Chem. Educ., 93(1), 13-23. DOI: http://10.1021/acsjchemed.5b00717.

Sapling (2016), Austin, TX: Sapling Learning, Inc. Retrieved from http://www2.saplinglearning.com/.

Scantlebury K. and Boone W. J., (2008), Designing Tests and Surveys for Chemical Education Research, in Bunce D. M. and Cole R. S. (ed.) ACS Symposium Series 976: Nuts and Bolts of Chemical Education Research, Washington, D.C.: American Chemical Society, pp. 149-170.

Scheg, A. G. (ed.), (2015), Implementation and Critical Assessment of the Flipped Classroom Experience, Hershey, PA: Information Science Reference.

Schneider B. and Blikstein P., (2016), Flipping the Flipped Classroom: A Study of the Effectiveness of Video Lectures Versus Constructivist Exploration Using Tangible User Interfaces, IEEE Trans. Learn. Technol., 9(1), 5-17. DOI: http://10.1109/TLT.2015.2448093.

Chemistry Education Research and Practice, Vol. 17 (2016): pg. 914-922. DOI. This article is @ Royal Society of Chemistry and permission has been granted for this version to appear in e-Publications@Marquette. Royal Society of Chemistry does not grant permission for this article to be further copied/distributed or hosted elsewhere without the express permission from Royal Society of Chemistry. 
NOT THE PUBLISHED VERSION; this is the author's final, peer-reviewed manuscript. The published version may be accessed by following the link in the citation at the bottom of the page.

Schultz D., Duffield S., Rasmussen S. C. and Wageman J., (2014), Effects of the Flipped Classroom Model on Student Peformance for Advanced Placement High School Chemistry Students, J. Chem. Educ., 91, 1334-1339.

Seery M. K., (2015), Flipped learning in higher education chemistry: emerging trends and potential directions, Chem. Educ. Res. Pract., 16, 758-768. DOI: 10.1039/c5rp00136f.

Seery M. K. and Donnelly R., (2012), The implementation of pre-lecture resources to reduce in-class cognitive load: a case study for higher education chemistry, Br. J. Educ. Technol., 43(4), 667677. DOI: http://10.1111/j.1467-8535.2011.01237.x.

Shaffer S., (2016), One High School English Teacher: On His Way to a Flipped Classroom, J. Adolesc. Adult Lit., 59(5), 563-573. DOI: http://10.1002/jaal.473.

Sirhan G. and Reid N., (2001), Preparing the Mind of the Learner - Part 2, Univ. Chem. Educ., 5, 52-58.

Sirhan G., Gray C., Johnstone A. H. and Reid N., (1999), Preparing the Mind of the Learner, Univ. Chem. Educ., 3, 43-46.

Smith J. D., (2013), Student attitudes toward flipping the general chemistry classroom, Chem. Educ. Res. Pract., 14(4), 607-614. DOI: 10.1039/c3rp00083d.

Sockalingam S., James S. L., Sinyi R., Carroll A., Laidlaw J., Yanofsky R. and Sheehan K., (2016), A Flipped Classroom Approach to Improving the Quality of Delirium Care Using an Interprofessional Train-the-Trainer Program, J. Continuing Educ. Health Prof., 36(1), 17-23. DOI: http://10.1097/CEH.0000000000000025.

Sohrabi B. and Traj H., (2016), Implementing flipped classroom using digital media: a comparison of two demographically different groups perceptions, Comput. Hum. Behav., 60, 514-524. DOI: http://10.1016/j.chb.2016.02.056.

Stephens J. M., Young M. F. and Calabrese T., (2007), Does moral judgment go offline when students are online? A comparative analysis of undergraduates' beliefs and behaviors related to conventional and digital cheating, Ethics Behav., 17(3), 233-254.

Sweet D., (2014), Microlectures in a Flipped Classroom: Application, Creation and Resources, MidWestern Educational Researcher, 26, 52-59.

Trogden B. G., (2015), The View from a Flipped Classroom: Improved Student Success and Subject Mastery in Organic Chemistry, in Scheg A. G. (ed.) Implementation and Critical Assessment of the Flipped Classroom Experience, Hershey, PA: Information Science Reference.

Tucker B., (2012), The Flipped Classroom, Educ. Next, 12, 82-83.

van Merrienboer J. J. G. and Sweller J., (2005), Cognitive load theory and complex learning: recent developments and future directions, Educ. Psychol. Rev., 17(2), 147-177. DOI: http://10.1007/s10648-005-3951-0.

Weaver G. C. and Sturtevant H. G., (2015), Design, Implementation, and Evaluation of a Flipped Format General Chemistry Course, J. Chem. Educ., 92, 1437-1448. DOI: http://10.1021/acs.jchemed.5b00316.

Wieczkowski J., Anselmi L. M., Maguire S. E. and Mayberry M. M., (2016), Flipping Anthropology: an assessment of student knowledge and evaluation in a flipped introductory anthropology course, Am. J. Phys. Anthropol., 159, 333-334.

Wilson M., (2003), On Choosing a Model for Measuring, Methods Psychol. Res. Online, 8, 1-22. Yestrebsky C., (2015), Flipping the Classroom in a Large Chemistry Class-research University Environment, Procedia - Soc. Behav. Sci., 191, 1113-1118.

Chemistry Education Research and Practice, Vol. 17 (2016): pg. 914-922. DOI. This article is @ Royal Society of Chemistry and permission has been granted for this version to appear in e-Publications@Marquette. Royal Society of Chemistry does not grant permission for this article to be further copied/distributed or hosted elsewhere without the express permission from Royal Society of Chemistry. 
NOT THE PUBLISHED VERSION; this is the author's final, peer-reviewed manuscript. The published version may be accessed by following the link in the citation at the bottom of the page.

Yeung K. and O'Malley P. J., (2014), Making 'the flip' work: barriers to and implementation strategies for introducing flipped teaching methods into traditional higher education courses, New Dir., 10, 59-63.

Yu Z. G. and Wang G. F., (2016), Academic Achievements and Satisfaction of the Clicker-Aided Flipped Business English Writing Class, Educ. Technol. Soc., 19(2), 298-312. 